\title{
LOCAL CONTENT AND NATIONAL TELEVISION IN PROVINSI RIAU
}

\author{
M.Y. Tiyas Tinov, Sujianto, Muchid Albintani \\ Faculty of Social and Political Sciences, Universitas Riau, Pekanbaru, Indonesia \\ mytinov_fisipunri@ymail.com, \\ sujianto@unri.ac.id, \\ muchid@lecturer.unri.ac.id
}

\begin{abstract}
Local content broadcasts that are required through the [SSJ] network broadcast system are deemed not fulfilled by national television operating in Riau Province. National television which is required to provide 10 percent of local content broadcasts in accordance with the provisions of the broadcasting law, and the regulations of the Indonesian broadcasting commission [KPI] are considered to ignore it. This study aims, first, to explain the support of national television media for broadcasting local content in Provinsi Riau. Second, explaining the constraints on national television supporting local content broadcasts in Provinsi Riau. This study uses Government Communication and Political Economy Media as its theoretical framework. A qualitative approach with descriptive analysis method was used in this study. Data is collected based on documents supported by interviews. After collecting the data, it is analyzed qualitatively. The study results conclude, first, that the 10 percent media support for local content broadcasting has not yet been fulfilled due to the centralized national media broadcasting program. Second, the constraints that cause not yet fulfilled the support of providing 10 percent of local content broadcasts, national television generally still prioritizes business interests.
\end{abstract}

\section{Keywords: Local Content, National Television, Provinsi Riau.}




\section{INTRODUCTION}

This paper is a preliminary study that examines the communication links between government and political economy media. In the context of these relationships the more specific study between political communication [government], and Political Economy [Media] becomes Political Communication Economics. Both aspects of this relationship include the provision of local content broadcasts by national television [government communication] in Riau with the obligation to broadcast local content according to regulations [based on laws, KPI regulations, and local regulations]. Local content broadcasts are considered strategic which can be used as a medium for developing local potential in the region. The development of local potential can be achieved through the application of local content in national television broadcasts. In practice, national television has not accommodated and provided information to regional communities, especially at the border. This means that the information presented on national television, is not always relevant and useful for the people in the area.

The theme of this conference, "Government Resilience Policy and Sustainable Development Goals", is an effective and strategic reminder of the issue of local content [local resilience related to local wisdom that supports the realization of local identity] supporting the sustainability of local identity development [local wisdom], and the sustainability of the engagement function national television [national television business] is important to be carried out especially in areas that have international borders, such as Provinsi Riau. The relationship of local content with national television in Riau as a study area has several reasons that support it. [1] Consistency of the national government, and regional governments in support of integrated local content. [2]. National television broadcast policy centered in Riau Province ignores broadcast local content that is not up to 5 percent. [3]. Riau Vision 2020 first supports local content before the broadcasting law. [4]. Riau Province which has international, coastal and island border areas.

This study can contribute to, As a comparative study if regulations between the national government [national television] and Provinsi Riau are related to the same policy [Riau Vision 2020]. Based on this explanation, this study aims, explaining the support of national television in carrying out local content broadcasts and their constraints in Provinsi Riau.

\section{LITERATURE REVIEW}

Literature review seeks to explain previous studies which are a reference to compare the importance of this study. Then explain the use of Communication Economy Politics as a theoretical framework to understand the relationship of local content broadcasts with national television media.

\subsection{Previous Studies}

The study of the relationship of local content broadcasts with national television in Riau, which has international, coastal and island border areas, needs serious attention, focus and integration. Related to this study [local content] are, Juditha study (2015); Supadiyanto (2015); and Ardiyanti (2011). Based on these three studies, this paper focuses its study on the relationship of local content broadcasts to national television. 
This study examines from the perspective of Government Communication and Politics of Media Economy into Political Communication of Economics which examines media relations [national television], and government regulation [local content broadcasts]. What distinguishes this study is, [1]. Limited studies that explain the relationship of local content broadcasts with the obligation [the existence of] national television in the [Riau] area. Most studies look at precisely the opposite that has led to the contribution of local media to fight for local content. [2]. The struggle of the regional government to support local content [local identity and local wisdom] was carried out before the national government. [3]. The same desire is not yet integrated with the regulations made by the [national-local] government as an affirmative action of local content.

\subsection{Local Content and Media Business: Communication Construction Government- Politics Economy Media}

Simplify analyzing the concept of local content broadcasts [Government Communication] with the concept of national television [Political Economy of Media] and their relationship, academic explanation is needed. It is important to convey that the context of this explanation is an initial attempt to understand the importance of the relationship of local content broadcasts and national television through a network broadcast system [SSJ]. Various literatures examine for example, (Nugroho, 2004); (Hasan, 2005); Fisher \& Horsley (2007); (Albintani, 2014); and (Abidin, 2016) in government communication. While in the political economy of media, such as Mosco (2009); Adila (2011), and Sarwoprasodjo (2008) provide an academic justification for the importance of a study of local content based on national television policies broadcasting 10 percent of affirmative action policies. In this context, theoretically if this study needs to be focused on clarifying the relationship of the government as a regulator with the entrepreneurs who organize the broadcast. The meeting point of this study as a positive contribution to the follow-up of studies that have been done a lot before.

Government Communication. Understanding of government communication previously explained Nugroho (2004); Hasan (2005); Fisher \& Horsley (2007), Albintani (2014), and Abidin (2016), provide references regarding the issue of government communication, which is interpreted as an approach to examine the way the government [executive], which essentially communicates regulatory products for the benefit of the [public] community. The government in this context is not only interpreted as a national government [the President and his staff], or a regional government [the governor and his staff] (Albintani, 2001), but also a state institution whose task is to accommodate the public interest as broadcasting supervisors.

Political Economy Media. In this study what is meant by the Politics of Media Economy is an approach to understanding the regulations associated with the conduct of the media business. The motivation behind making a regulation [broadcasting law] which requires national television to broadcast 10 percent local content.

Political Economic Communication. Theoretically, this study needs to be focused on clarifying the relationship between government as regulators and entrepreneurs as broadcast providers [media business]. The meeting point of the study as a positive contribution to follow-up that has not been done much by previous reviewers (as a 
comparison, Albintani (2016), has already begun. Or how to construct a preferred approach to understanding the phenomena of media empowerment fulfilling the 10 percent local content obligation.

Local Content. The term local content [a term in regulation] is known since local television developed rapidly in various regions. Local content, or local content, was introduced by the Indonesian Broadcasting Commission (KPI) through the Broadcast Behavior Guidelines (KPI Regulation/1/2012), and the 2012 Broadcast Program [P3SPS]. This local content is intended to assist the audience in interpreting messages. What is meant by local content in this study is local content or content that includes journalistic broadcasts, factual programs and non-factual programs in national television broadcasts in Riau through the Network Broadcast System [SSJ].

National Television. What is meant by national television is the national television media which has conducted SSJ in Riau, including PT. RCTI 10 [RCTI Riau], PT. Trans TV Pekanbaru-Padang [Trans TV Pekanbaru], PT. Trans 7 LampungPekanbaru [Trans 7 Pekanbaru], PT. Mahardika Maha Negeri [RTV Pekanbaru], PT. Lativi Mediakarya Medan and Pekenbaru [TV One Pekenbaru], PT. Cakrawala Andalas Television Pekanbaru and Papua [ANTV Pekanbaru], PT. Surya Citra Pesona Media [SCTV Pekanbaru], PT. Media Televisi Nusantara Enam [Metro Pekanbaru], PT. Indosiar Pekanbaru Television [Indosiar Pekanbaru].

\section{METHOD}

This study uses a qualitative approach with descriptive analysis methods. Data is collected based on documents supported by interviews. After collecting the data, it is analyzed qualitatively.

\section{MEDIA IDENTITY AND NATIONAL MEDIA BUSINESS IN THE REGIONS}

Examining local content, the implementation of national television broadcasting in each region, the readiness of regional television in maintaining local content with a variety of problems, along with many studies conducted by previous researchers. It has been explained previously that the importance of studies with the theme of local content, national media broadcasts in the regions, and the importance of this study were carried out. More specifically, the focus of this study explains the relationship between local content and national television broadcasts in the region, Riau. This study reinforces the explanation of two things. First, media identity as a result of the issuance of local and national regulations. Second, the media business in regions that have not been able to meet the local content network broadcasting system content of 10 percent.

\subsection{Local Media Identity Policy}

Examining local content and relations with the national television broadcasting organization in the regions has various problems. This study specifically identifies local policy relationships that maintain local content as local identity, which is always referred to as local wisdom. In this connection too, national television operating in the regions will also be directly localized [a term to indicate that there is involvement of national media broadcasting local content], which is in Riau. 
In connection with this involvement, it needs to be said if Riau compared to other regions, has significant differences. Riau is the only one who has a vision beyond Indonesia. Although it had become a polemic, the explanation related to the vision of Riau 2020 which made, "Riau as the center of Malay culture in Southeast Asia in 2020" (Local Regulation [Perda]/1/2004), is no longer a problem. Important study findings show that the Riau Vision 2020 is a 'trademark', a characteristic of national television media operating in Riau. Riau Vision 2020 is also a protection related to media identity that likes, or does not become, a characteristic as a local content in running the national television SSJ in accordance with its ten percent requirement.

Based on this explanation, examining the relationship of local content and with the holding of national television broadcasts in Riau, the problem is centered broadcasting. The centralized broadcast method becomes an argument as well as proving that national television does not yet support local content broadcasts. Regarding centralized national television broadcasting, table 1 below as a study finding can explain it.

Table. 1

Local Content Network Broadcasting System (SSJ) in Riau PT. Trans 7 Lampung Pekanbaru

\begin{tabular}{|l|l|l|l|l|l|}
\hline No. & $\begin{array}{l}\text { Program } \\
\text { Name }\end{array}$ & $\begin{array}{l}\text { Hour } \\
\text { Live }\end{array}$ & $\begin{array}{l}\text { Showtime/ } \\
\text { Duration }\end{array}$ & $\begin{array}{l}\text { Suitability } \\
\text { Program }\end{array}$ & Showing \\
\hline 1. & Dunia & $02.30-$ \\
& Binatang & Nonconformity & Nonconformity & Riau \\
\hline 2. & Tau Nggak Sih & $\begin{array}{l}05.30- \\
06.00 \mathrm{Wib}\end{array}$ & Nonconformity & Nonconformity & Riau \\
\hline 3. & Jejak Si & $\begin{array}{l}06.00- \\
06.30 \mathrm{Wib}\end{array}$ & Nonconformity & Nonconformity & Riau \\
\hline 4. & Wundul & $\begin{array}{l}03.30- \\
04.00 \mathrm{Wib}\end{array}$ & Nonconformity & Nonconformity & $\begin{array}{l}\text { Pulau } \\
\text { Penyengat }\end{array}$ \\
\hline 5. & Warna Riau & $\begin{array}{l}04.30- \\
05.00 \mathrm{Wib}\end{array}$ & Nonconformity & Nonconformity & Riau \\
\hline
\end{tabular}

Source: KPID Riau 2018, and processed by the author.

Table 1, which is a study finding, explains the lack of fulfillment of 10 percent of the network broadcast system [SSJ] on all national television stations operating in Riau. For the sample taken is Trans 7, is nothing but a network broadcast system that has just been evaluated by Riau KPID. Even so, it can be ascertained that for other national television, the conditions are not much different.

Referring to data according to table 1, it can be explained in more detail. This is for example, the World of Animals broadcast, the results of the KPID assessment, the program is not in accordance with data from broadcasters. In addition, based on the data on local content displayed from 3:15 a.m., the television was broadcast from 2:30 a.m.

Furthermore, the Tau Nggah Sih broadcast, which was broadcast time, did not match the data from the broadcasting institution. Based on data from the Tau Gak Sih 
Program which aired at 4:45 a.m.-05:15 a.m., on the Tv aired at 05:30 a.m.-06:00 a.m. In the meantime, broadcast of the track of the Gundul, broadcasting broadcast time is not in accordance with data from broadcasters. From the data, this program will be aired at 3 : 15Wib-3:45 a.m., while on the TV it will be aired at 6:00 a.m. -06:30 a.m. For programs aired in the regions, the Warna Riau broadcast program aired on Penyengat Island [Pulau Penyengat], Riau Islands [Kepulauan Riau], not Riau. The 'Warna Riau' Program was also aired in the meaningful Kuantan Singingi area in Riau.

Based on the data that has been explained, it shows that broadcast centralization is the main cause of the lack of fulfillment of 10 percent local content broadcasts through SSJ. The study also found that national television carried out only relayed central broadcasts, in an effort to meet 10 percent of local content. Content incompatibility and airtime, does not burden television. As input from the study findings for non-state supervisory institutions [broadcasting commissions], it is considered necessary to have such local content broadcast indicators.

\subsection{Local Content Broadcasts in Constraints}

Furthermore, this study explains the obstacles that have not yet met the support of providing ten percent of local content broadcasts, among others, the media are generally still prioritizing business interests. As explained in the previous literature review, it can provide arguments related to the interests of the television business. The political economy approach of the media provides the basis for argumentation if the capitilias principle of the capital owner is unlikely to be managed based on social interests. Although the government has sought support to develop local content through policy, reality shows the opposite. Television media [political economy communication] with the principle of capitalist economy, although the government holds regulatory rights to defend, and symbolize its local culture, but various steps that have been taken, are still defeated by the shrewdness of the ability of political actors in economic communication [media business organizers].

Many studies in this scope, including this study found that television entrepreneurs can always take advantage of loopholes in existing regulations. As explained earlier that for Riau, broadcasting regulations require 10 percent time for local content broadcasts under the name Network Broadcast System (SSJ). The relaxation is, in addition to not meeting the percentage, the businessman also broadcasts local content broadcasts in the early hours of the morning, so that it can be judged far away from the audience.

The study found that according to the report of the Chairperson of the Riau Regional Indonesian Broadcasting Commission [KPID] delivered at the KPI national coordination meeting in Makassar, March 30- April 2, 2015, there were 11 national television stations implementing the SSJ with the program name, duration, and time taken. To find out, it can be examined according to table 2 below. 
Proceeding ICOGISS 2019

Page 811-819. ISBN: 978-602-6 988-75-1

Web Jurnal Online: jurnal.unmuhjember.ac.id By: M.Y. Tiyas Tinov; Sujianto; Muchid Albinti Local Content And National Television In Provinsi Riau

Table. 2

National television implements network broadcast system (SSJ)

local content in Riau 2009-2018

\begin{tabular}{|c|c|c|c|c|}
\hline No & $\begin{array}{l}\text { COMPANY/ } \\
\text { TELEVISION }\end{array}$ & EVENT NAME & $\begin{array}{c}\text { TIME/ } \\
\text { DURATION } \\
{[\%]}\end{array}$ & EXPLANATION \\
\hline 1. & $\begin{array}{lcc}\text { PT. } & \text { TPI } 6 \\
{[\text { MNC }} & \text { Riau }]\end{array}$ & $\begin{array}{l}\text { Pancing, } \\
\text { Jendela, } \\
\text { anak-anak, } \\
\text { Wisata }\end{array}$ & $\begin{array}{l}90 \text { minute }[7,5 \\
\text { from } 10]\end{array}$ & Since June 2014 \\
\hline 2. & $\begin{array}{l}\text { PT. GTv Lima } \\
\text { [Global Tv } \\
\text { Pekanbaru] }\end{array}$ & $\begin{array}{l}\text { - Not yet obtained } \\
\text { information }\end{array}$ & $\begin{array}{l}30 \text { minute }[2,2 \\
\text { from } 10]\end{array}$ & $\begin{array}{l}\text { Since October } 2014 \\
\text { (without } \\
\text { information on the } \\
\text { name of the event } \\
\text { and the time of the } \\
\text { show). }\end{array}$ \\
\hline 3. & $\begin{array}{l}\text { PT. RCTI } 10 \\
\text { [RCTI Riau] }\end{array}$ & $\begin{array}{l}\text { Gapura [Pekanbaru } \\
\text { azan time ] }\end{array}$ & $\begin{array}{l}03.00-04.00 / 60 \\
\text { minute }[4,3 \text { dari } \\
10]\end{array}$ & Since July 2014 \\
\hline 4. & $\begin{array}{l}\text { PT. Trans TV } \\
\text { Pekanbaru- } \\
\text { Padang [Trans } \\
\text { TV } \\
\text { Pekanbaru] }\end{array}$ & Pesona Riau & $\begin{array}{l}03.00-04.00 / 60 \\
\text { minute }[4 \text { from } \\
10]\end{array}$ & Since \\
\hline 5. & $\begin{array}{ll}\text { PT Trans } & 7 \\
\text { Lampung- } & \\
\text { Pekanbaru } & \\
\text { [Trans } & 7 \\
\text { Pekanbaru] } & \end{array}$ & $\begin{array}{ll}\text { Warna } & \text { Riau } \\
\text { [Pekanbaru } & \text { azan } \\
\text { time] } & \end{array}$ & $\begin{array}{l}03.30-04.30 / 60 \\
\text { minute }[4,3 \text { from } \\
10]\end{array}$ & Since August 2018 \\
\hline 6. & $\begin{array}{l}\text { PT. Mahardika } \\
\text { Maha Negeri } \\
\text { (RTV } \\
\text { Pekanbaru) }\end{array}$ & $\begin{array}{ll}\text { Kabar } & \text { Kota } \\
\text { Pekanbaru } & \end{array}$ & $\begin{array}{l}120 \text { minute }[7.5 \\
\text { from } 10]\end{array}$ & Since 2009 \\
\hline 7. & $\begin{array}{l}\text { PT. Lativi } \\
\text { Mediakarya } \\
\text { Medan dan } \\
\text { Pekanbaru } \\
{[\text { TV One }} \\
\text { Pekenbaru] }\end{array}$ & $\begin{array}{l}\text { - Not yet obtained } \\
\text { information }\end{array}$ & $\begin{array}{l}03.30-04.30 / 90 \\
\text { minute }[6 \text { from } \\
10]\end{array}$ & Since January 2014 \\
\hline 8. & $\begin{array}{l}\text { PT Cakrawala } \\
\text { Andala } \\
\text { Televisi } \\
\text { Pekanbaru dan }\end{array}$ & $\begin{array}{l}\text { Cahaya Hati } \\
\text { Magazine }\end{array}$ & $\begin{array}{l}03.30-04.00 \\
07.00-07.30 / \\
60 \text { minute ( } 4 \text { from } \\
10]\end{array}$ & Since January 2014 \\
\hline
\end{tabular}




\begin{tabular}{|c|c|c|c|c|}
\hline & $\begin{array}{l}\text { Papu [ANTV } \\
\text { Pekanbaru] }\end{array}$ & & & \\
\hline 9. & $\begin{array}{l}\text { PT Surya Citra } \\
\text { Pesona Media } \\
\text { [SCTV } \\
\text { Pekanbaru] }\end{array}$ & $\begin{array}{l}\text { Religi Mata Air } \\
\text { Berita Lokal }\end{array}$ & $\begin{array}{l}04.30-05.00 \\
06.30-07.00 / \\
\text { minute }\left[\begin{array}{lr}4 & \text { from } \\
10\end{array}\right]\end{array}$ & Since 2014 \\
\hline 10. & $\begin{array}{l}\text { PT MEDIA } \\
\text { Televisi } \\
\text { Nusantara } \\
\text { Enam [Metro } \\
\text { Pekanbaru] }\end{array}$ & $\begin{array}{l}\text { Pesona Sumatera } \\
\text { Riau Sepekan }\end{array}$ & $\begin{array}{l}04.00-05.00 \\
13.00-14.00 / 120 \\
\text { minute }[7,5 \text { from } \\
10]\end{array}$ & Since 2014 \\
\hline 11. & $\begin{array}{l}\text { PT Indosiar } \\
\text { Pekanbaru } \\
\text { Televisi } \\
\text { [Indosiar } \\
\text { Pekanbaru] }\end{array}$ & $\begin{array}{lr}\text { Bike to } & \text { nature, } \\
\text { Catatan } & \text { harian } \\
\text { santri, } & \text { Teropong, } \\
\text { Menuju } & \text { Rumah } \\
\text { Ilahi, } & \text { Jelajah } \\
\text { Masjid, Horison }\end{array}$ & $\begin{array}{l}03.00-04.00 / 30 \\
\text { minute }[2 \text { from } \\
10]\end{array}$ & Since 2014 \\
\hline
\end{tabular}

Source: Report of Riau KPID at the National KPI coordination meeting in Makassar [March 30-April 2 2015] and by the author.

Understanding tables. 2, when compared temporarily with centralized broadcasts, and delays as flashbacks, the study findings show that if the national television business operators in the regions are very dependent on the consistency of national television operators broadcasting local content. This reality clarifies the findings of previous studies if the media business becomes more important compared to the 10 percent obligation to broadcast SSJ in the regions.

\section{CONCLUSION}

The study results concluded, firstly, that centralized broadcasting was the cause of the 10 percent national television support not being met for local content broadcasts through the network broadcast system [SSJ]. Local content broadcasts can be effectively carried out in accordance with regulations, only if there is support from the national government, national television providers, regional governments, broadcast monitoring institutions. Secondly, the interests of the national television business which are prioritized by the organizers are the constraints causing 10 percent of local content not being fulfilled. Integrated evaluations by broadcast watchdog institutions [national and regional KPI], supported by stakeholders related to the implementation of SSJ are the key to failure, or the successful fulfillment of 10 percent of local content broadcasts in Riau. 


\section{REFERENCES}

1) Albintani, M. (2001). Dari Riau merdeka sampai otonomi nol. Pekanbaru: Unri Press.

2) Albintani, M. (2014). "Kecerdasan identitas dan kekuatan komunikasi: menuju Indonesia yang demokratis. dalam buku,"Demokratitasi masyarakat plural: gasa depan komunikasi, masa depan Indonesia". Editor Billy K Sarwono dkk. Jakarta: Ikatan Sarjana Komunikasi Indonesia: (hal.1-19).

3) Albintani, M. (2016). Political economy communication perspective: The 'relationship' between capitalism and illegal logging in Riau, Indonesia. International Journal of Sustainable Development. 4(9): 19-24.

4) Adila, I. (2011). Spasialisasi dalam politik ekonomi komunikasi (studi kasus MRA media). Jurnal Ilmu Komunikasi. 1 (1): 94-104.

5) Ardiyanti, H. (2011). Konsep dan regulasi tv lokal dalam kerangka penguatan budaya lokal. Jurnal Politica Dinamika Masalah Politik Dalam Negeri dan Hubungan Internasional. 2 (2): 323-340.

6) Abidin, Y.Z. (2016). Komunikasi pemerintahan: filosofi, konsep dan aplikasi. Jakarta: Pustaka Setia.

7) Fisher, B. and Horsley, J. S. (2007). The government communication decision wheel: toward a public relations model for the public sector'. Journal of Public Relations Research. 19(4): 377-93.

8) Hasan. (2005). Komunikasi pemerintahan. Bandung: Refika Aditama.

9) Juditha, C. (2015). Televisi lokal dan konten kearifan lokal (studi kasus di Sindo Tv Kendari). Jurnal Penelitian Komunikasi dan Pembangunan. 16. 49-64.

10) Mosco, V. (2009). The political economy of communication: second edition. London: Sage.

11) Nugroho, R. (2004). Komunikasi pemerintahan sebuah agenda bagi pemimpin pemerintahan Indonesia. Jakarta: Elex Media Komputindo, Kelompok Gramedia.

12) Peraturan Daerah Provinsi Riau No.1 Tahun 2004 tentang, "Rencana strategis Provinsi Riau Tahun 2004-2008."

13) Peraturan Daerah Provinsi Riau No.1 Tahun 2012 tentang, "Lembaga Adat Melayu Riau."

14) Peraturan Komisi Penyiaran Indonesia No.01/p/kpi/03/2012 tentang, "Pedoman perilaku penyiaran dan standar program siaran."

15) Supadiyanto. (2015). Implementasi program siaran lokal pada stasiun televisi di Daerah Istimewa Yogyakarta. Jurnal An-Nida, 7 (2): 66-78. 